\title{
ORGANIC PRODUCTION IN THE EUROPIAN UNION AND BULGARIA - MAIN CROP
}

\author{
P. Branzova* \\ Department "Regional and Sector Economics", Economic Research Institute, \\ Bulgarian Academy of Sciences, Sofia, Bulgaria
}

\begin{abstract}
The purpose of the report is to outline the overall picture of organic production of the main agricultural crops in the EU and Bulgaria. An important aspect is the type of production (arable land and orchard) of organic farms. The choice of type of production differs between regions and Member States and depends on various factors (including the technical aspects related to organic production and the structure of consumer demand). In the course of the study, the methods of comparison, statistical methods, etc. are used. The results are aimed at identifying existing differences between EU countries in the field of organic production development.
\end{abstract}

Key words: Bio production, agriculture, organic farming

\section{An overview of the production of organic products}

With more than 11 million hectares of certified area or area under conversion in 2015 , organic farming made up $6.2 \%$ of the European Union's (EU) total Utilized Agricultural Area (UAA). (1) Since 2010, the area devoted to organic farming has grown by almost two million hectares. Similarly, an upward trend can be observed for the number of registered organic producers. At the end of 2015, 271500 organic agricultural producers were registered in the EU, an increase of $5.4 \%$ compared with 2014.

Among Member States, Spain, Italy, France and Germany registered the largest organic areas as well as the largest numbers of organic producers in 2015, accounting together for over half $(52 \%)$ of both total EU organic crop area and organic producers in the EU.

The part of agricultural land farmed organically differs widely between EU Member States. The highest share of crop area dedicated to organic farming was registered in Austria, with one fifth $(20 \%$, or 552 thousand

\footnotetext{
*Correspondence to: Petia Branzova, Department "Regional and Sector Economics", Economic Research Institute at Bulgarian Academy Of Sciences, Sofia, Aksakov Str.3, Phone: 0889 759 968, E-Mail: petia.branzova@gmail.com
}

hectares) of its total agricultural area farmedorganically in 2015. It was followed by Sweden $(17 \%$, or 519 thousand hectares) and Estonia (16\%, or 156 thousand hectares). Alongside these top performers, the Czech Republic (14\%, or 478 thousand hectares), Italy (12\%, or 1493 thousand hectares) and Latvia (12\%, or 232 thousand hectares) also reported over $10 \%$ of agricultural land farmed organically.

In contrast, organic farming was not strongly developed in three Member States with the area under organic farming below $2 \%$ of agricultural land: in Malta $(0.3 \%$, or 30 hectares), Ireland $(1.6 \%$, or 73 thousand hectares)and Romania (1.8\%, or 246 thousand hectares). (2)

It should be noted that the importance of the organic sector is generally lower in regions with plains where more intensive production systems prevail.

At EU level, the area dedicated to production of organic crops in 2015 has increased by $21 \%$ since 2010 to slightly more than 11 million hectares, with the landmark of 10 million hectares having been reached in 2012. Organic land area has risen over this period in all Member States, except the United Kingdom $(-29 \%)$ and, to a lesser extent, the Netherlands $(-4 \%)$. In contrast, Croatia (from 16 
thousand hectares of organic land in 2010 to almost 76 thousand hectares in 2015 , or $+377 \%)$ and Bulgaria $(+362 \%)$ recorded an almost fourfold increase of their land devoted to organic farming. They were followed at a distance by France $(+61 \%)$, Ireland $(+53 \%)$, Lithuania $(+49 \%)$ and Cyprus $(+48 \%)$.

\section{ANALYSIS OF ORGANIC PRODUCTION -MAIN CROP}

An important aspect is the type of production (arable crop and orchard) on the organic farms. The choice of the type of production differs among regions and Member States and depends on various factors (among which the technical aspects related to organic production and the structure of consumer demand).

\subsection{The arable crop and orchard production}

\subsubsection{Analysis by main categories}

In the European Union, organic arable crop and orchard production is important. Though data is scarce on all categories of this type of production, Table 1 gives an idea of the main types of land use for organic arable crop and orchard production. A good share of the organic land is used for permanent grasslands, but also for permanent crops (such as fruit) as well as cereals. When looking at the area under organic farming in comparison to the total area for the different agriculturaluses in Europe, available data shows that organic organic crops (total) represent $5 \%$ of the total area cultivated in the EU-28.

The comparison of the main use categories for the organic sector shows interesting features. The share of permanent crops is high in the organic sector $(15 \%)$ because the demand for fruit and vegetable products is among the highest on the organic market. What is significant is the share of permanent grassland which represents more than $50 \%$ of the whole organic area.

Conversely, cereals cover more than $30 \%$ of the total UAA of the EU but a lower percentage of the organic UAA. One element of explanation lies in the fact that organic production systems are more extensive than in conventional agriculture (higher reliance on grazing on permanent pastures).(3) Permanent pastures are often eligible for agrienvironmental organic payments and easier and less risky to convert to the organic sector than the other types of crops (e.g. arable crops). Depending on national features of rural development agri-environmental and/or organic payments and land use characteristics at regional level, this could lead to a bias towards the development of organic permanent pastures.

\subsubsection{Permanent pastures}

At Member State level, the area under permanent pastures is the highest in absolute terms in Spain, Germany, the United Kingdom, the Czech Republic, France and Italy where it is around 0.4 million ha or more.

\subsubsection{Major arable crops: cereals, oilseeds and protein crops}

Among the arable crops, cereals represent the most important category with 1.4 million ha in 2015 , i.e. $14.6 \%$ of all EU organic land. This represents $2.5 \%$ of the total EU cereal area.

The largest cereal areas are located in Germany and Italy (around 0.20 million ha) and in Italy and Spain (around 0.2 million ha each). In 2015, France, the largest EU producer of cereals, grew more than 186000 ha of organic cereals. Poland comes fifth with more than 101000 ha. Among the constraints that impede the development of arable crops in the organic sector, pest control and management have already been mentioned. Other factors play a role, in particular weed management which, in the case of wheat, is often cited as the main technical difficulty faced in the organic sector as the use of chemical herbicides is prohibited. In addition, a major impediment is probably the absence of resources for development of new cereal varieties, which would not have to be controlled through the use of regular pesticides and fertilisers.

The organic oilseed area is estimated at around 212214 ha in 2015 , and the area dedicated to industrial crops around 273087 ha in 2015 for the EU-28.

Another important category of arable crops is dried pulses, which play a specific role in the organic sector. Firstly, because dried pulses are leguminous plants which fix nitrogen they have a high rotational value in the organic production systems, contributing to the maintaining of soil fertility. Crop rotation is also a legal obligation under Council Regulation (EC) No 834/2007. Secondly, dried pulses play an important role in organic animal feed as they can substitute other protein feed ingredients (e.g. organic soybeans) which may be difficult to procure. In addition, the use of on-farm cultivated protein crops for organic animal feed in mixed crop-livestock production systems ensures the traceability of protein feed ingredients. It is estimated that 
301461 ha of organic dried pulses were cultivated in 2015 in the EU-28, of which $80 \%$ in the EU-15. France is the largest organic dried pulse producer with more than 68000 ha in 2015, followed by Spain, Italy and Germany, with around 39000 ha, 37000 ha and 33 000ha respectively.

\subsubsection{Vegetables}

The vegetable sector represents a minor part of the organic area: 145639 ha in 2015. Most of the area is concentrated in the EU-15 (97 201 ha, $66 \%$ of all EU-28 organic vegetable area). Even if the N-13 Member States, with 48438 ha, cover only $44 \%$ of the EU-28 vegetable organic area, it is one EU-N13 country, Poland, which is the Member State with the largest area of organic vegetables (41 $819 \mathrm{ha}$ ). Italy follows with more than 29487 ha, France being third with 16832 ha. Spain stands at 13 578 ha whereas Germany accounts for 11190 ha in 2015 .

\subsubsection{Permanent crops}

A sub-section is dedicated to permanent crops because they are an important category, fruit being a noteworthy product on the organic market. At the EU level the organic area of permanent crops amounts to more than 1.2 million ha.

In 2015 , olives represented $34 \%$ of the organic permanent crop area (454 227 ha) in the EU28 , followed by fruit $(25 \%, 333569$ ha) and grapes $(21 \%, 281722 \mathrm{ha})$.

\subsubsection{Grapes}

EU organic vineyards are mostly located in the EU-15. In 2015, Spain cultivated 96591 ha of grapes, followed by Italy (83 643 ha) and France (70 496 ha). Germany shows a total organic grape area of 6766 ha, Greece of 5 431 ha, Austria of 5100 ha, surfaces which are on an upward trend and Portugal with 2719 ha. In the EU-N13, Bulgaria takes the lead with 4199 ha of vineyards, followed by Hungary with 1325 ha, the Czech Republic with 1021 ha and Croatia with 913 ha. The organic grape area for the top three mentioned countries seems to have followed a constant increasing trend.

\subsubsection{Nuts}

In 2015, there were 190580 ha of organic nuts in the EU, of which only 23494 ha in the EU13 (with most important areas in Bulgaria, Poland and in Hungary. In the EU-15, the 167 086 ha of organic nuts are primarily located in Spain and Italy.

At the EU level the nuts and olive sectors are two important sectors in the permanent crop organic areas in 2015 (14\% for nuts and 34\% for olives) since these two types of production are faced with a high demand on the market (especially organic olive oil) together with lower difficulties in carrying out production from an agronomic point of view. This cannot be said for instance of grape production as vines are very sensitive to diseases.

\subsection{State of Organic Production in Bulgaria in 2015}

In the last few years the organic production in the country has been developing at a rapid pace, with an increase in both the number of operators and the areas and the number of animals included in a control system. In Bulgaria, there are very good prerequisites for the development of organic production ecologically preserved areas. The development of the sector is stimulated by the opportunities to support organic producers under the Rural Development Programs and the efforts of the MAF, in partnership with the business and non-governmental organizations in the sector, to promote the benefits for the producers and consumers of this type of products and foods. The growing number of producers, processors and traders joining the organic production control and certification system shows that more and more people are aware of the benefits of this type of production. More and more manufacturers are turning to organic production, and more and more consumers are looking for healthy and unpolluted fertilizer and other chemical ingredients production. The motivation of both producers and consumers is a consequence of care for the ecological balance of land and for our own health.

2.2.1. Areas in control system In 2015, the areas covered by the organic production control system reach 118571 ha (excluding certified green areas from which wild crops are harvested), which is nearly $60 \%$ more than in the previous year. In 2015, the control areas occupy a share of $2.4 \%$ of the total utilized agricultural area in the country and $1.9 \%$ of the total areas declared under the SAPS, respectively $1.5 \%$ and $0.96 \%$ in 2014 . (4) By the end of 2015, 21543 ha or $18.2 \%$ of the total areas of the control system for the year have passed a transition period. Organically grown grain crops are 22,191 hectares in 2015 , with over $80 \%$ compared to the previous year, mainly wheat, maize, barley, rye, oats and triticale.

The areas occupied by technical crops in a control system in 2015 are 20873 ha (including areas with oil rose, aromatic crops, medicinal plants and spices). Compared to 
2014 , they grow by nearly 8,000 ha as a result of a significant increase in sunflower and radish areas.

There is a significant increase in the area of aromatic crops, medicinal plants and spices, which reach 11456 ha, at 7754 ha in 2014 . The largest share of this group of crops occupies the lavender area, which amounts to 3 412 ha, followed of those with 2,481 ha of coriander and 1,735 hectares of fry. An increase of nearly $30 \%$ compared to the previous 2014 is also seen in the group of fresh vegetables such as artichokes, onions, carrots, lettuce, cauliflower and broccoli, watermelons, melons, strawberries and cultivated mushrooms. The largest share of this group of crops is artichoke - 480 ha and pumpkin - 393 ha.

Almost 50\% is the increase on an annual basis of the areas with permanent meadows and pastures, which at the end of 2015 already have 31796 ha. Growth of 3115 hectares compared to 2014 also includes arable land areas (Green Crops), due to the increased interest on the part of the operators in organic livestock farming.

Areas under permanent crops grown biologically in 2015 amount to 25,946 ha, which is 7,734 ha more than in the previous year. Growth is mainly due to the growth of areas with stone and pome fruits, nuts and vines.

For all species in the perennial plant group, there was an increase of the areas in a control system relative to 2014. The interest in the group of nutraceutical species - nuts, hazelnuts, almonds and chestnuts continues to grow. In 2015, the area of this crop group increased to 15,366 ha, to 10,257 ha in 2014 or nearly $50 \%$. The increase is due to an increase in the area of nuts - from 7199 ha in 2014 to 11340 ha in 2015, while the other species have seen a slight decline.
The interest in organic cultivation of vineyards continues to increase, from 3543 ha in 2014 at the end of 2015 to 4199 ha. The increase is due to the increase of the areas of wine varieties from 3298 ha to 4013 ha, whereas in the case of dessert varieties a decrease of 245 ha in 2014 to 186 ha by the end of 2015 .

Organically grown crops from the group of grain legumes, protein crops for grain production (including seed and mixtures of cereals and legumes), which grow to 1257 ha, at 404 ha in 2014, are also reported for the second year Although a small proportion of cultivated areas continues to occupy a control system, the area of root crops (potatoes and beets) has also increased - from 78 ha in 2014 to 103 ha in 2015 .

Organically grown non-traditional crops, such as artichokes - 480 ha and kiwi - 2.9 ha, albeit in small areas, show the efforts of organic farmers to respond to market demand and diversify the crops they cultivate. Certified ecologically clean areas from which wild berries, herbs and mushrooms are harvested in 2015 amount to 901,617 ha, which is more than 200,000 ha or almost $30 \%$ more than in the previous year.

\section{CONCLUSIONS}

The organic farming sector in EU and Bulgaria has rapidly developed in the past years. This increase characterises not only the area under organic farming, but also the number of holdings and of overall organic operators registered in the EU-28. Though a good part of the number of holdings and area is still situated in the EU-15, the EU's newest Member States have shown encouraging developments in this respect, in particular in the context of additional financing provided by the EU for this type of production since their accession. An arable crop and orchard organic production are on an upward trend in the EU Member States. Organic farms are on the average larger than non-organic farms.

Table 1. Main categories of certified organic land use in the EU-28, 2015

\begin{tabular}{|l|l|l|l|}
\hline & $\begin{array}{l}\text { Organic } \\
\text { Land (ha) }\end{array}$ & $\begin{array}{l}\% \text { of total } \\
\text { organic }\end{array}$ & $\begin{array}{l}\% \text { of total } \\
\text { UAA } \\
\text { (conventional } \\
\text { and organic) } \\
\text { per category }\end{array}$ \\
\hline Total crops & 8829622 & $100 \%$ & $5.1 \%$ \\
\hline Cereals & 1691451 & $19.2 \%$ & $2.9 \%$ \\
\hline Dried pulses & 301461 & $3.4 \%$ & $21.3 \%$ \\
\hline Industrial crops & 273087 & $3.1 \%$ & $2.2 \%$ \\
\hline Permanent grassland & 5156341 & $58.4 \%$ & $10.6 \%$ \\
\hline Permanent crops & 1322516 & $15 \%$ & $12.8 \%$ \\
\hline
\end{tabular}

Source: Eurostat data land use statistics and Eurostat data on the basis of Council Regulation (EC) No 834/2007 on organic Production (online data code: org_cropar) 
STATISTICAL SOURCES AND

REFERENCES

Statistical sources

Eurostat database:

http://ec.europa.eu/eurostat/data/database

FAOSTAT:

http://www.fao.org/faostat/en/\#home

Farm Accountancy Data Network (FADN):

http://ec.europa.eu/agriculture/rica/database/da tabase_en.cfm

\section{REFERENCES}

1. Organic crop area on the rise in the EU, 208/2016 - 25 October 2016, Eurostat News release;
2. Willer $H$. and Lernoud J. Organic Agriculture Worldwide 2017: Current Statistics, Research Institute of Organic Agriculture (FiBL), Frick, Switzerland BIOFACH 2017, February 15, 2017 www.fibl.org

3. European Commission (2016) Facts and figures on organic agriculture in the European Union;

4. Ministry of Agriculture, Food and Forestry, Annual Report on Situation and Development of Agriculture (Agriculture Report 2016). 